\title{
Theoretical investigation of 3 '-subtituted-2'-3'-dideoxythymidines related to AZT. QSAR infrared and substituent electronic effect studies
}

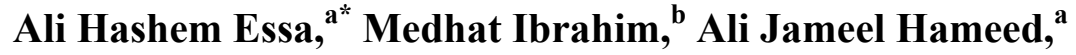 \\ and Najim A. Al-Masoudi ${ }^{*}$ \\ a. Department of Chemistry, College of Science, University of Basrah, Basrah, IRAQ \\ ${ }^{b}$ Spectroscopy Department, National Research Centre, Dokki, Cairo, Egypt \\ c. Fachbereich Chemie, Universität Konstanz, D-78457 Konstanz, Germany (formerly) \\ *Email: alihashemalyunis@yahoo.com; Najim.Al-Masoudi@gmx.de
}

\begin{abstract}
Several substituted 3'-azido-3'-deoxythymidine derivatives have been theoretically investigated by performing the BLYP to obtain approximate minimum energy structures, as well as the DZVP basis set. A quantitative structure-activity relationship (QSAR) of the same series, in regard to their anti $\mathrm{HIV}$, has been studied. The substituents investigated are $\mathrm{X}=\mathrm{N}_{3}, \mathrm{H}, \mathrm{Cl}, \mathrm{F}$, $\mathrm{CH}_{3}, \mathrm{OCH}_{3}, \mathrm{COCH}_{3}$ and $\mathrm{COOH}$ as well as the linearity groups such as $-\mathrm{NO},-\mathrm{N}=\mathrm{CHAr}$, and $\mathrm{CN}$. The vibrational spectrum was calculated beyond the harmonic approximation. The correlation analysis of $v_{\mathrm{OH}}$ values failed to correlate with substituent Hammett's $\sigma$ parameter. The electrondonating groups at C-3' of the thymidine derivatives are more suitable than $\mathrm{N}_{3}$ group and would increase the electron density on the $\mathrm{C}_{5},-\mathrm{OH}$ group.
\end{abstract}

Keyword: 3'-Azido-2',3'dideoxythymidine (AZT), infrared study, substituent electronic effects, Hammett's equation, QSAR

\section{Introduction}

The most widely used clinical therapeutic agent against the human immunodeficiency virus type $1(\mathrm{HIV}-1)^{1,2}$ is the nucleoside 3'-azido-2',3'-dideoxythymidine (AZT), which is the potent inhibitor of HIV reverse transcriptase enzyme responsible for AIDS. ${ }^{3}$ However, intensive efforts are still needed for the development of novel, more efficacious, and selective nucleoside derivatives since the therapeutic potential of AZT is limited by serious adverse reactions, particularly bone marrow suppression. ${ }^{2}$ An attractive approach to overcome the drawbacks of AZT and improve its efficacy is the synthesis of ddT (1) and FddT (2). ${ }^{4}$ 

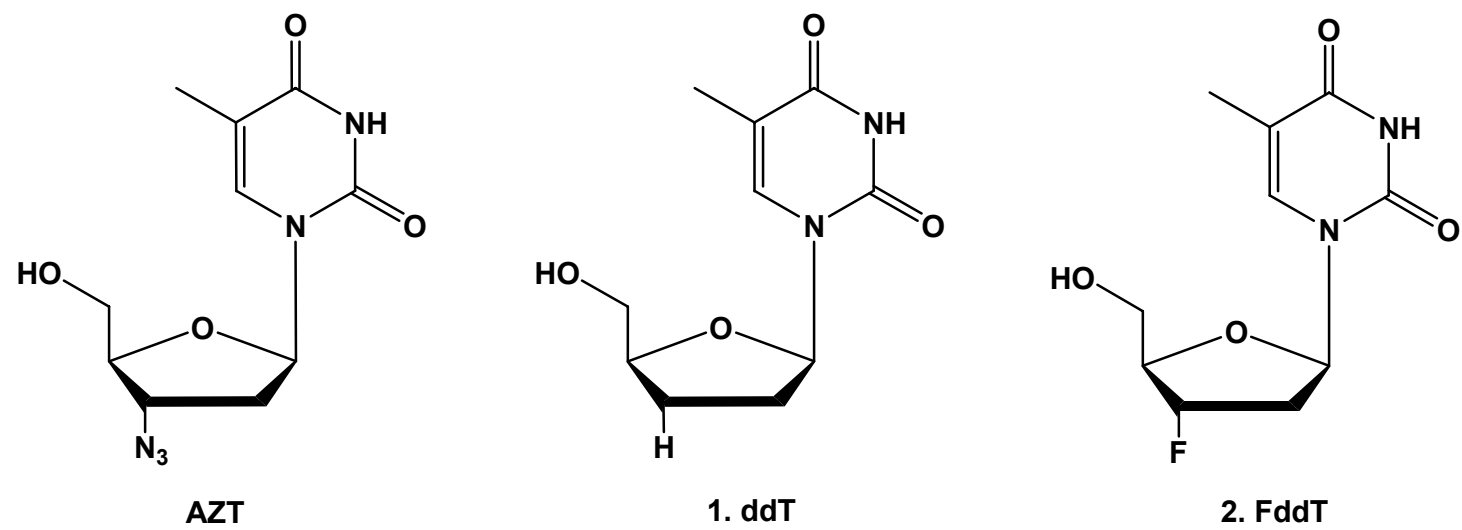

2. FddT

Figure 1. The chemical structures of AZT, ddT and FddT

The discovery of ddT and FddT as potent inhibitors of HIV reverse transcriptase (RT) marked a decisive advance in the search for anti- AIDS drugs. However, the long-term administration of these compounds to AIDS patients is limited by a number of severe side effects $^{5}$ and by appearance of drug resistant HIV strains. ${ }^{6}$ In the search for new, longer acting, more selective, and less toxic anti-HIV agents, a wide range of 2',3'- dideoxynucleoside analogues have been prepared. ${ }^{7}$ Interested by structure-activity relation studies in this area, many researchers initiated a program several years back to examine the influence of substitution at N-3 position of the thymine base of AZT and other 2',3'-dideoxynucleoside analouges on HIV replication. ${ }^{8-12}$ Assuming that such molecules inhibit RT in the same manner as AZT itself, one might anticipate that N-3 substitution would alter base-base interactions at several levels and, in particular, in their capacity to act as chain terminators. ${ }^{13}$ Recently, we have synthesized ${ }^{12}$ new derivatives of AZT substituted by alkyl and alkylsulphonyl groups at N-3 and C-5', respectively, and were found less cytotoxic to MT-4 cells, than AZT. In connection with our mentioned results, the QSAR and DFT properties of various derivatives of AZT substituted by thio and methyl groups at C-5' as well as AZT itself have been investigated theoretically ${ }^{14}$ by applying semi-empirical molecular orbital theory and density functional theory (B3LYP/3-21G). The substituents were: $\mathrm{H}, \mathrm{SH}, \mathrm{SCl}, \mathrm{SF}_{3}, \mathrm{SCN}, \mathrm{SOMe}, \mathrm{SO}_{2} \mathrm{Me}$, SMe, SSMe, SCOMe, SEt, and $\mathrm{SO}_{2}$ Et. The result indicated that the selected analogues possessed the same electronic properties, and some showed higher activity than AZT.

The action mechanism of AZT on HIV-RT is postulated through the phosphorylation of $\mathrm{C}_{5^{\prime}}$ $\mathrm{OH}$ of AZT to its triphophate followed by the penetration of the immune cell T4 envelope, via $\mathrm{CD}+$ receptor-gp120, resulting subsequently in the inhibition of RT.

Based on these observations, we describe here the IR spectra of a series of 2'-deoxy-3'substituted-thymidine analogues related to AZT, bearing structurally and electronically diverse substituents at the $\mathrm{C}-3$ ' position of the sugar ring. 


\section{Calculation details}

All calculations were carried out using D-Gauss program package MOPAC 2002, as implemented in the CAChe program. ${ }^{15}$ The initial geometry optimization of AZT and the thymidine analogues 1-11 (Figure 1) (X= H, F, Cl, $\mathrm{CH}_{3}, \mathrm{OCH}_{3}, \mathrm{COCH}_{3}, \mathrm{CO}_{2} \mathrm{H}, \mathrm{NO}, \mathrm{CN}, \mathrm{NCO}$ and $\mathrm{N}=\mathrm{CHAr}$, respectively) were performed using the BLYP to obtain approximate minimum energy structures, as well as the DZVP basis set. The vibrational spectrum was calculated beyond the harmonic approximation.

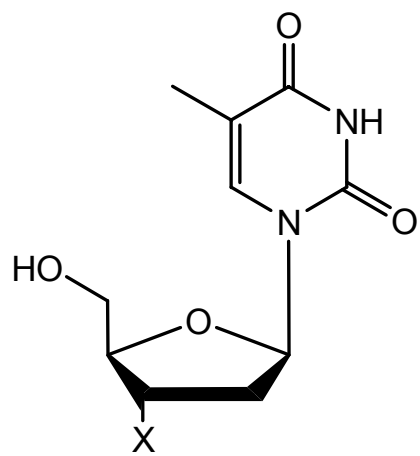

Figure 2. Schematic diagram indicates the structure of AZT $(X=N 3)$ and thymidines $(1-11)$

\begin{tabular}{l|lllllllllll} 
& $\mathbf{1}$ & $\mathbf{2}$ & $\mathbf{3}$ & $\mathbf{4}$ & $\mathbf{5}$ & $\mathbf{6}$ & $\mathbf{7}$ & $\mathbf{8}$ & $\mathbf{9}$ & $\mathbf{1 0}$ & $\mathbf{1 1}$ \\
\hline $\mathbf{X}$ & $\mathrm{H}$ & $\mathrm{F}$ & $\mathrm{Cl}$ & $\mathrm{CH}_{3}$ & $\mathrm{OMe}$ & $\mathrm{COMe}$ & $\mathrm{CO}_{2} \mathrm{H}$ & $\mathrm{NO}$ & $\mathrm{CN}$ & $\mathrm{NCO}$ & $\mathrm{NCHAr}$
\end{tabular}

\section{Results and Discussion}

\section{Infrared Spectra}

The calculated vibrational spectrum has proved to be a powerful tool to investigate changes in molecular aggregation, orientation, and structure at the level of functional groups. ${ }^{16}$ AZT normal structure showed three nitrogen atoms attached linearly to the furanose ring as indicated in Figure 1. The optimized structure is corresponding to $C_{1}$ molecular point group. The IR spectrum of AZT, calculated by BLYP/DZVP model, is presented in Figure 2a. A weak OH band is raised at $3625 \mathrm{~cm}^{-1}$, whereas the bending band appeared at a lower frequency $\left(226 \mathrm{~cm}^{-1}\right)$ as a weak band. The vibrational bands of NH stretching of the amide I is appeared at $3492 \mathrm{~cm}^{-1}$, while the $\mathrm{N}-\mathrm{H}$ bending, which is coupled with the C-N stretching mode (amide II), appeared at $1404 \mathrm{~cm}^{-1} \cdot{ }^{17} \mathrm{C}-\mathrm{H}$ vibrations exhibit several bands in the spectrum of AZT. ${ }^{18,19} \mathrm{C}-\mathrm{H}$ symmetric stretching is located at $2967 \mathrm{~cm}^{-1},{ }^{18,19}$ while other $\mathrm{C}-\mathrm{H}$ bands are oriented at $1249 \mathrm{~cm}^{-1}\left(\mathrm{CH}_{3}\right), 1056 \mathrm{~cm}^{-1}\left(\mathrm{CH}_{2}\right.$ scissoring; furanose) and $494 \mathrm{~cm}^{-1}\left(\mathrm{CH}_{2} \mathrm{OH}\right)$, respectively. The band at $2103 \mathrm{~cm}^{-1}$ is assigned to $\mathrm{N} \equiv \mathrm{N}$ vibration. The characteristic band for this structure is the amide I band; mainly $\mathrm{C}=\mathrm{O}$ 
stretching vibration which is located at $1678 \mathrm{~cm}^{-1} .{ }^{20}$ Other bands could be attributed to the vibrations of furanose ring of the AZT. Replacement of the azide residue of the furanose ring by $\mathrm{H}, \mathrm{F}, \mathrm{Cl}, \mathrm{CH}_{3}, \mathrm{OCH}_{3}, \mathrm{COCH}_{3}, \mathrm{CO}_{2} \mathrm{H}, \mathrm{NO}, \mathrm{CN}, \mathrm{NCO}$ and $\mathrm{N}=\mathrm{CHAr}$ groups is reoptimzed in comparison to the spectrum of AZT, where is calculated at the same level of theory. Generally, the molecular point group $\left(\mathrm{C}_{1}\right)$ is retained. The IR spectrum of some selected structures is indicated separately in Figures 2a-d. For comparison purposes, the total spectra of 1-11 are plotted in Figure 2d and Table 1, where each band of 1-11 is plotted in comparison to those of AZT to asses the effect of substituent. The OH band $\left(3625 \mathrm{~cm}^{-1}\right)$ of $\mathbf{2}$ and $\mathbf{3}$ is derived toward higher frequencies, corresponding to $\mathrm{Cl}$ and $\mathrm{F}$ atoms, and toward the lower frequencies, corresponding to other substituents. Except nucleosides having $\mathrm{H}$ and $\mathrm{N}=\mathrm{CHAr}$ groups ( 1 and 11, respectively), amide I is slightly shifted toward the higher frequencies, whereas the amide II is shifted toward the lower frequencies. There is no major spectral shifting for the amide I band; while a major shifting in $\mathrm{CH}$ vibrations is considered. As AZT interacts with Lipid Stratum Corneum (SC) lipids; changes in the position of AZT bands are noticed, and such changes are due to the formation of hydrogen bonding. ${ }^{20}$ Accordingly, we could attribute the changes in the band positions due to the hydrogen bonding in 1-11 $\left(\mathrm{X}=\mathrm{H}, \mathrm{F}, \mathrm{Cl}, \mathrm{CH}_{3}, \mathrm{OCH}_{3}, \mathrm{COCH}_{3}, \mathrm{COOH}\right.$, $\mathrm{NO}, \mathrm{CN}, \mathrm{NCO}$ and NCHAr), which drives the bands of 1-11 in comparison to those of AZT itself. It is worthy to mention that a unique $\mathrm{N}=\mathrm{C}=\mathrm{O}$ vibration band was observed at $2278 \mathrm{~cm}^{-1}$ attributed to the NCO substituent. In addition, the ring vibration is given in the range 1455-1462 $\mathrm{cm}^{-1}$ assigned to the NCHAr substituent. Furthermore, the same group gives rise to $\mathrm{CH}$ vibrations at $2995 \mathrm{~cm}^{-1}$ and $2878 \mathrm{~cm}^{-1}$. 

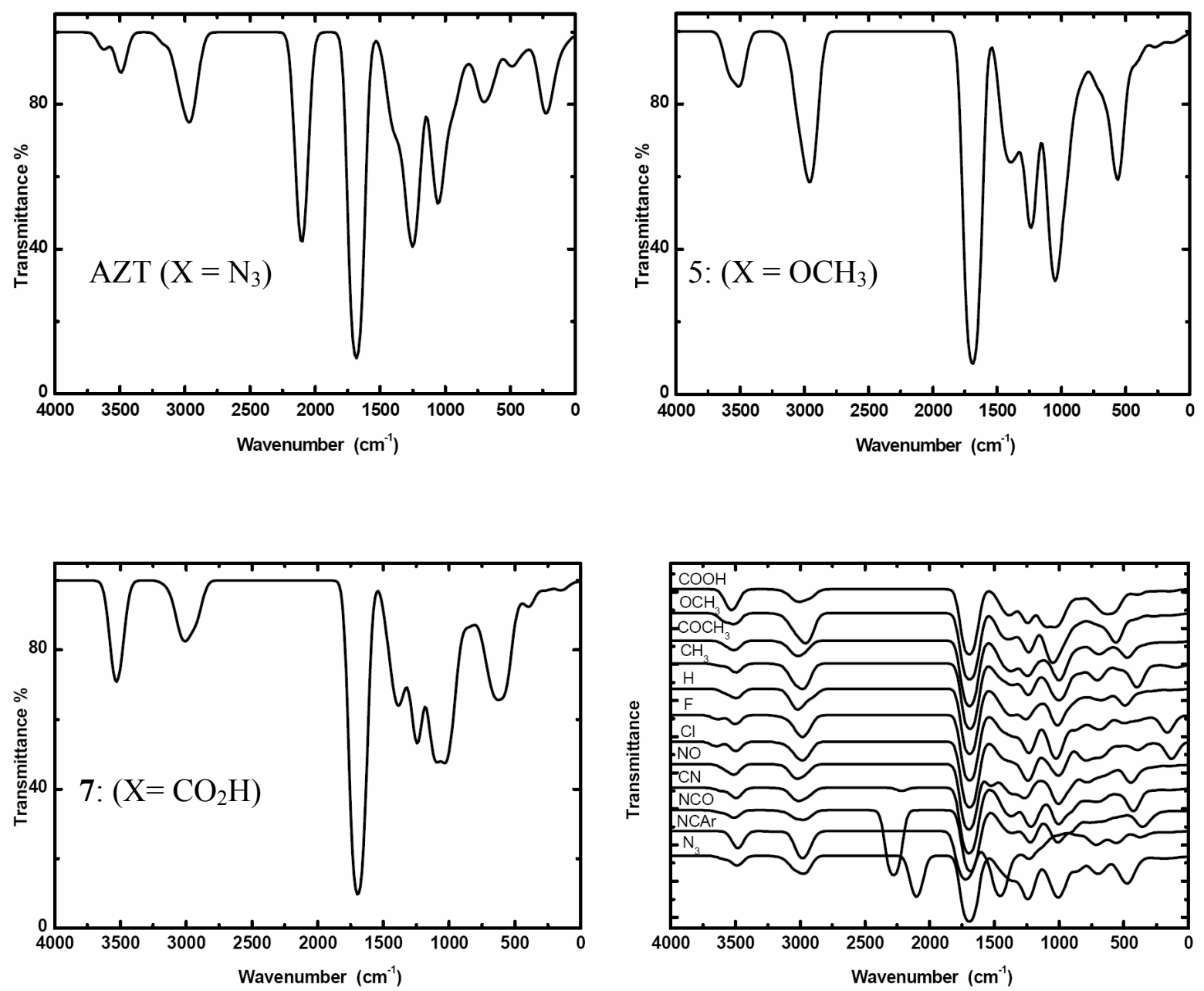

Figure 2. Infrared spectra of AZT and 1-11, calculated with BLYP/DZVP. 
Table 1. Calculated IR spectra of AZT and the nucleosides 1-11 with band assignment.

\begin{tabular}{|c|c|c|c|c|c|c|c|c|c|c|c|c|}
\hline \multirow{2}{*}{ Vibration } & \multicolumn{12}{|c|}{$X$} \\
\hline & $\mathrm{N}_{3}$ & $\mathrm{H}$ & $\mathrm{Cl}$ & $\mathrm{F}$ & $\mathrm{CH}_{3}$ & $\mathrm{OCH}_{3}$ & $\mathrm{COCH}_{3}$ & $\mathrm{COOH}$ & $\mathrm{NO}$ & $\mathrm{CN}$ & $\mathrm{NCO}$ & NCHAr \\
\hline \multirow[t]{2}{*}{$\mathrm{OH}$} & 3625 & 3612 & 3648 & 3638 & 3612 & 3583 & 3640 & 3591 & 3586 & 3609 & 3630 & 3540 \\
\hline & 226 & ----- & 133 & 166 & 92 & ----- & ----- & ----- & 449 & 426 & 341 & ----- \\
\hline \multirow[t]{2}{*}{$\mathrm{NH}$} & 3492 & 3488 & 3496 & 3501 & 3495 & 3498 & 3501 & 3497 & 3507 & 3494 & 3508 & 3476 \\
\hline & 1404 & 1373 & 1377 & 1371 & 1382 & 1336 & 1372 & 1241 & 1217 & ----- & 1371 & ----- \\
\hline CHAr & ----- & ----- & ----- & ----- & ----- & ----- & ----- & ----- & ----- & ----- & ----- & 1455 \\
\hline Ring & ----- & ----- & ----- & ----- & ----- & ----- & ----- & ----- & ----- & ----- & ----- & 1462 \\
\hline \multirow[t]{2}{*}{ CH-Ring } & ----- & ----- & ----- & ----- & ----- & ----- & ----- & ----- & ----- & ----- & ----- & 2995 \\
\hline & ----- & ----- & ----- & ----- & ----- & ----- & ----- & ----- & ----- & ----- & ----- & 2978 \\
\hline \multirow[t]{3}{*}{$\mathrm{CH}$} & ----- & 3022 & 2981 & 2982 & 3002 & 2977 & 3011 & 3021 & 3029 & 3027 & 3024 & 3027 \\
\hline & 2967 & 3005 & ----- & ----- & 2969 & 2965 & 2936 & 2969 & 3002 & 2992 & 2972 & 3005 \\
\hline & 1056 & 1013 & 1009 & 1029 & 1010 & 1044 & 1005 & 1096 & 1017 & 1008 & 1011 & 1012 \\
\hline $\mathrm{C}=\mathrm{N}$ & ----- & ----- & ----- & ----- & ----- & ----- & ----- & ----- & ----- & 2215 & ----- & ----- \\
\hline $\mathrm{CH}_{2}$ & 715 & 667 & 811 & 694 & 708 & 560 & 682 & 619 & 799 & 766 & 664 & 664 \\
\hline $\mathrm{N} \equiv \mathrm{N}$ & 2103 & ----- & ----- & ----- & ----- & ----- & ----- & ----- & ----- & ----- & ----- & ----- \\
\hline $\mathrm{N}=\mathrm{C}=\mathrm{O}$ & ----- & ----- & ----- & ----- & ----- & ----- & ----- & ----- & ----- & ----- & 2278 & ----- \\
\hline $\mathrm{C}=\mathrm{O}$ & 1683 & 1683 & 1679 & 1681 & 1681 & 1673 & 1677 & 1680 & 1678 & 1683 & 1678 & 1684 \\
\hline Furanose & 494 & 492 & 389 & 509 & 402 & 443 & 471 & 397 & 459 & 456 & 558 & 583 \\
\hline
\end{tabular}




\section{Correlation Analysis}

The theoretical analysis of various empirical substituent constants related to intramolecular inductive, resonance, or steric effects, in terms of the quantum-chemical characteristics of the molecules has been of substantial theoretical and pragmatic interest. ${ }^{21,23}$

The correlation analysis is failed to show a cross linkage of $v_{\mathrm{OH}}$ against substituent Hammett's $\sigma$ parameter ${ }^{24,25}$ (Figure 3a). A Correlation has been shown, however, between $\sigma$ and $v_{\mathrm{OH}}$ in case of considering the electronic properties of each substituent separately. This has been illustrated graphically in Figure $3 b$.

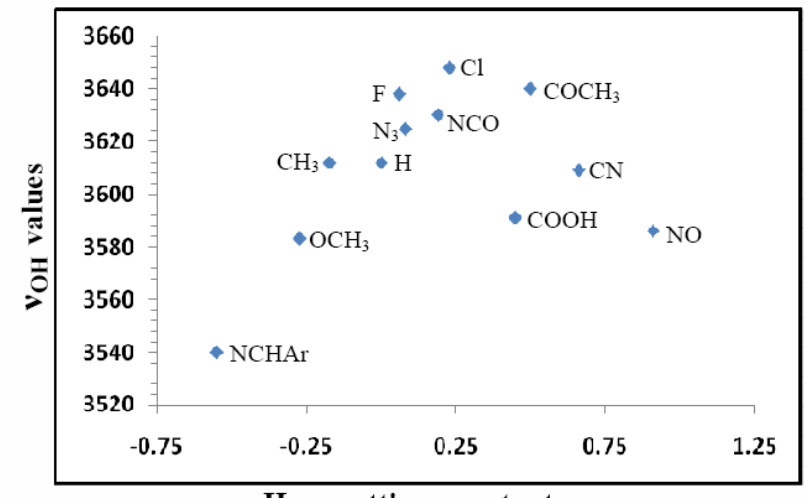

Hammett's $\sigma$ constants

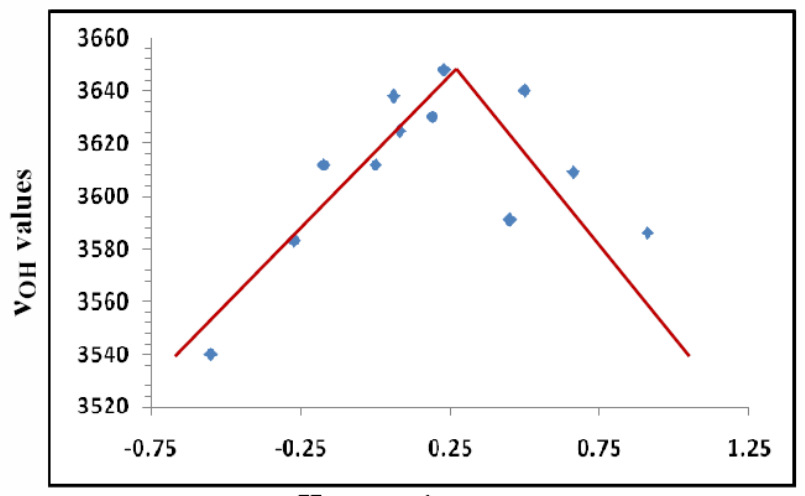

Hammett's $\sigma$ constants

(a)

(b)

\begin{tabular}{l|cccccccccccc} 
Sub. & $\mathrm{N}_{3}$ & $\mathrm{H}$ & $\mathrm{Cl}$ & $\mathrm{F}$ & $\mathrm{CH}_{3}$ & $\mathrm{OCH}_{3}$ & $\mathrm{COCH}_{3}$ & $\mathrm{COOH}$ & $\mathrm{NO}$ & $\mathrm{CN}$ & $\mathrm{NCO}$ & $\mathrm{NCHAr}$ \\
\hline$\sigma$ constants & 0.08 & 0 & 0.23 & 0.06 & -0.17 & -0.27 & 0.5 & 0.45 & 0.91 & 0.66 & 0.19 & -0.55
\end{tabular}

Figure 3. Plot of Hammett's $\sigma$ parameter versus $v_{\mathrm{OH}}$ values in $\mathrm{AZT}$ and 1-11.

The mono substituent parameter (MSP) analysis of the $v_{\mathrm{OH}}$ values for donating and withdrawing groups is given by Equation 1 and 2, respectively.

$$
v_{\mathrm{OH}}=3623+118 \sigma^{\mathrm{BA}}
$$

$\mathrm{s}=9.502, \mathrm{r}=0.945, \mathrm{~F}=25.34$

$$
v_{\mathrm{OH}}=3726-365 \sigma^{\mathrm{BA}}
$$

$\mathrm{s}=40.39, \mathrm{r}=0.878, \mathrm{~F}=3.37$

where $\mathrm{r}$, s and $\mathrm{F}$ represent the correlation coefficient, standard deviation of regression, and Fisher ratio. The high value of the correlation coefficient (r), and the lowest values of s would confirm the high stability of the model.

The positive sign for $\rho$ (Equation 1) is indicative of a so-called "normal" substituent effect. It indicates that donors would induce downfield shifts, while the negative sign for $\rho$ (Equation 2 ) is indicative of a reverse substituent effect.

Increasing of oxygen charge of $\mathrm{C}_{5^{\prime}}-\mathrm{OH}$ makes compounds 1-11 more electrophilic and then faster in reactivity with high stereoselectivity. ${ }^{26}$ Accordingly, the analogues having electron-donating groups at C-3' would be more suitable for phosphorylation of $\mathrm{C}_{5^{-}} \mathrm{OH}$ than those of AZT. The final objective of this work is studying the quantitative chemical structure- biological activity relationship (QSAR). The selected QSAR properties of AZT and the nucleosides 1-11 are shown in Table 2. 
Table 2. Selected QSAR properties of AZT and the nucleosides 1-11, where $\mathrm{E}^{\mathrm{HYD}}$ is the hydration energy in $\mathrm{kcal} / \mathrm{mol}$

\begin{tabular}{|c|c|c|c|c|c|c|c|c|c|}
\hline Comp. & $X$ & $\log P$ & $\begin{array}{c}\text { Surface area } \\
\text { (Approx) }\end{array}$ & $\begin{array}{c}\text { Surface area } \\
\text { (Grid) }\end{array}$ & Volume $\left(\AA^{3}\right)$ & $\mathrm{E}^{\mathrm{HYD}}$ & $\begin{array}{c}\text { Refractivity } \\
\left(\AA^{3}\right)\end{array}$ & $\begin{array}{c}\text { Polarizability } \\
\left(\AA^{3}\right)\end{array}$ & Mass(amu) \\
\hline & $\mathrm{N}_{3}$ & 0.19 & 371.32 & 456.09 & 725.26 & -16.69 & 65.01 & 24.16 & 267.24 \\
\hline 1 & $\mathrm{H}$ & -0.86 & 339.26 & 406.82 & 640.56 & -5.35 & 54.65 & 21.53 & 226.23 \\
\hline 2 & $\mathrm{~F}$ & -0.69 & 339.10 & 410.76 & 648.34 & -4.89 & 53.75 & 21.44 & 244.22 \\
\hline 3 & $\mathrm{Cl}$ & -0.14 & 359.87 & 422.48 & 675.14 & -4.87 & 58.49 & 23.46 & 266.68 \\
\hline 4 & $\mathrm{CH}_{3}$ & -0.45 & 359.87 & 423.64 & 679.89 & -4.26 & 59.12 & 23.37 & 240.26 \\
\hline 5 & $\mathrm{OCH}_{3}$ & -1.01 & 379.48 & 443.53 & 711.71 & -5.31 & 60.19 & 24.00 & 256.26 \\
\hline 6 & $\mathrm{COCH}_{3}$ & -0.83 & 382.77 & 451.66 & 730.17 & -4.51 & 64.29 & 25.29 & 268.27 \\
\hline 7 & $\mathrm{CO}_{2} \mathrm{H}$ & -0.38 & 359.14 & 439.14 & 702.50 & -11.36 & 60.74 & 24.09 & 270.24 \\
\hline 8 & NO & -0.88 & 363.56 & 428.09 & 679.50 & -9.53 & 59.04 & 22.74 & 255.23 \\
\hline 9 & $\mathrm{CN}$ & -0.98 & 371.08 & 430.29 & 688.12 & -8.58 & 59.87 & 23.38 & 251.24 \\
\hline 10 & $\mathrm{NCO}$ & -1.24 & 401.33 & 449.36 & 716.99 & -6.72 & 60.52 & 24.03 & 267.24 \\
\hline 11 & NCHAr & 1.12 & 457.80 & 559.11 & 924.24 & -6.63 & 86.79 & 33.96 & 329.36 \\
\hline
\end{tabular}


Table 2 showed that $\log \mathrm{P}$ is the most important parameter, and considered as a consequence of the activation (hydroxylation) process, as well as involved in the interaction between the tested compounds, the phosphate groups, and the transport of compound derivatives across cell and nuclear membranes.

During the phosphorylation of 1-11, the coefficient of Log P is typically near unity. In such a reactions, there are a number of possibilities in which the coefficient is near -0.80 . By considering the variation of these values within a coefficient of 0.19 , Log P in Table 2 would be a weak argument for the hypothesis which explains the interaction between $\mathrm{C}_{5},-\mathrm{OH}$ of 1-11 and the phosphate groups.

In addition, surface area $(\mathrm{S})$, volume $(\mathrm{V})$, molar refractivity $(\mathrm{MR})$, hydration energy $\left(\mathrm{E}^{\mathrm{HYD}}\right)$ and mass are the main parameters in calculation of the whole structures of the studied molecules. ${ }^{27,28}$ The surface area and volume values explain the hypothesis that the more bulky chemical group would occupies larger values of surface and volume. In the present calculations, the total volume of the studied system are varied between $640.56 \AA^{3}$, for compound 1 (ddT, $\mathrm{X}=$ $\mathrm{H})$ and $924.24 \AA^{3}$ for compound $11(\mathrm{X}=\mathrm{NCHAr})$, while the surface area are varied between $339.10 \AA^{2}$ and $457.80 \AA^{2}$.

The trends of surface area and volume values are quite clear since the more bulky group possess the larger values of surface area and volume. Such trends are feasible to be analysed though small variations values of the studied molecules carrying a similar $\mathrm{X}$ group can be witnessed.

The polarizability is expected to be involved in our calculation, since it is directly proportionated to intrinsic molecular volume. The latter is a measure of energy needed to form a cavity in the solvent. Regarding the polarizability influence the more polar compound can be considered as the potent inhibitor which could leave the solvent bulk and absorbed by the phosphate groups, furnishing mono, di- and finally triphosphate analogues. The latter is, in turn, will penetrate into the immune cell T4.

\section{Conclusions}

According to the theoretical IR spectra, and correlation analysis, we concluded that the electrondonating groups at $\mathrm{C}-3$ ' of the thymidine derivatives would increase the electron density on the $\mathrm{C}_{5},-\mathrm{OH}$ group.

\section{References}

1. Arion, D.; Kaushik, N.; McCormick, N.; Borkow, G.; Parniak, M. A. Biochemistry 1998, 37, 15908. 
2. Zhang, R.; Lu, Z.; Diasio, C. R.; Liu, T.; Soong, S.-J. Antimicrob. Agents Chemother. 1993, 37, 1771.

3. Fischl, M. A.; Richman, D. D.; Grieco, M. H.; Gottlieb, M. S.; Volberding, P. A.; Laskin, O. L.; Leedom, J. M.; Groopman, J. E.; Mildvan, D.; Schooley, R. T.; Jackson, G. G.; Durack, D. T.; King, D. N. Engl. J. Med. 1987, 317, 185.

4. Adams, D. R.; Maillard, Ca. P. M.; Florent, J.; Evers, M.; He'nin, Y.; Litvak, S.; Litvak, J. L.; Monneret, J. C.; Grierson, D. S. J. Med. Chem. 1997, 40, 1550.

5. Herdewijn, P.; De Clercq, E. In: Design of Anti-Aids Drugs; De Clercq, E., Eds.; Elsevier Amsterdam, 1990; 141.

6. (a) Richman, D. D. Annu. Rev. Pharmacol. Toxicol. 1993, 32, 149. (b) De Clercq, E. Biochem. Pharmacol. 1994, 47, 155. (c) Larder, B. A.; Kemp, S. D. Science 1989, $246,1155$.

7. Nasr, M.; Litterest, C.; McGowan, J. Antiviral Res. 1990, 14, 125.

8. Maillard, M.; Florent, J.-C.; Lemaitre, M.; Begassat, F.; Bugnicourt, A.; Ferrieux, C.; Rombi, C.; Pacaud, E. D.; Thierry, D. E.; Zerial, A.; Monneret, C.; Grierson, D. S. Bioorg. Med. Chem. Lett. 1992, 2, 1469.

9. Kitade, Y.; Suzuki, A.; Hirota, K.; Maki, Y.; Nakane, H.; Ono, K.; Baba, M.; Shigeta, S. Chem. Pharm. Bull. 1992, 40, 920.

10. Sato, Y.; Utsumi, K.; Maruyama, T.; Kimura, T.; Yamamoto, I.; Richman, D. D. Chem. Pharm. Bull. 1994, 42, 595.

11. Yamamoto, I.; Kimura, T.; Tateoka, Y.; Watanabe, K.; Ho, I. K. J. Med. Chem. 1987, 30, 2227.

12. Al-Masoudi, N. A.; Al-Soud, Y. A.; Ali, I. A. I.; Schuppler, T.; Pannecouque, Ch.; De Clercq, E. Nucleosides Nucleotides Nucleic Acids 2007, 26, 223.

13. Huff, A. C.; Topal, M. D. J. Biol. Chem. 1987, 262, 12843.

14. Essa, A. H.; Al-Masoudi, N. A. J. Comput. Theor. Nanoscience 2008, in press.

15. MOPAC 2002 Version 2.5.3, J. J. P. Stewart, Fujitsu Limited, Tokyo, Japan.

16. Topacli, C.; Topacli, A.; Tes,neli, B.; Richardson, T.; Gümüs, G.; Ahsen, V. Vibrational Spectrosc. 2006, 40, 20.

17. Byler, M.; Susi, H., Biopolymers 1986, 25, 469.

18. Bouwstra, J. A.; Dubbelear, F. E. R.; Gooris, G. S.; Ponec, M. Acta Derm.-Venereol. 2000, $208,23$.

19. Gaudreau, S.; Neault, J. F.; Tajmir-Riahi, H. A. J. Biomolec. Struct. Dyn. 2002, 19, 1007.

20. Narishetty, S. T. K.; Panchagnula, R. J. Control. Release 2005, 102, 59.

21. Wu Y. D.; Wong C. L. J. Org. Chem. 1995, 60, 821.

22. Hayase S., Hrovat, D. A.; Borden W. T. J. Am. Chem. Soc. 2004, 126, 10028.

23. Essa A. H. Intern. J. Quan. Chem. 2007, 107, 1574.

24. Hansch, C.; Leo, A.; Taft R. W. Chem Rev. 1991, 91, 165.

25. Jovanović, S.; Mijin, D.; Mišić-Vuković, M. ARKIVOC 2006, (x), 116.

26. Nifantiev, E. E.; Grachev, M. K.; Burmistrov, S. Y., Chem. Rev. 2000, 100, 3755. 
27. Hansch, C.; Leo, A. Exploring QSAR: Fundamentals and applications in chemistry and biology, American Chemical Society: Washington, DC, 1995.

28. Atkin, P. W.; de Paula, J. Physical Chemistry, W. H. Freeman: New York, NY, 2002, Sections 21.2-4. 